Katinka Schulte-Ostermann

Das Problem der Handlungsverursachung

Eine kritische Untersuchung zur kausalen Handlungstheorie 


\title{
PRACTICAL PHILOSOPHY
}

\author{
Herausgegeben von / Edited by \\ Herlinde Pauer-Studer • Neil Roughley \\ Peter Schaber • Ralf Stoecker
}

Band 14 / Volume 14

The aim of the series is to publish high-quality work that deals with questions in practical philosophy from a broadly analytic perspective. These include questions in meta-ethics, normative ethics and "applied" ethics, as well as in political philosophy, philosophy of law and the philosophy of action. Through the publication of work in both German and English the series aims to facilitate discussion between English- and Germanspeaking practical philosophers. 


\author{
Katinka Schulte-Ostermann
}

\title{
Das Problem der Handlungsverursachung
}

Eine kritische Untersuchung zur kausalen Handlungstheorie

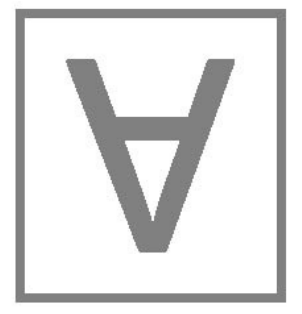

ontos

verlag 
Bibliographic information published by the Deutsche Nationalbibliothek

The Deutsche Nationalbibliothek lists this publication in the Deutsche Nationalbibliographie; detailed bibliographic data is available in the Internet at http://dnb.ddb.de

\title{
Dissertation der Universität Bonn
}

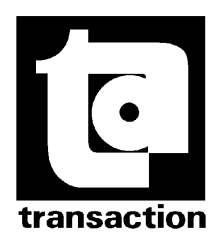

\author{
North and South America by \\ Transaction Books \\ Rutgers University \\ Piscataway, NJ 08854-8042 \\ trans@transactionpub.com
}

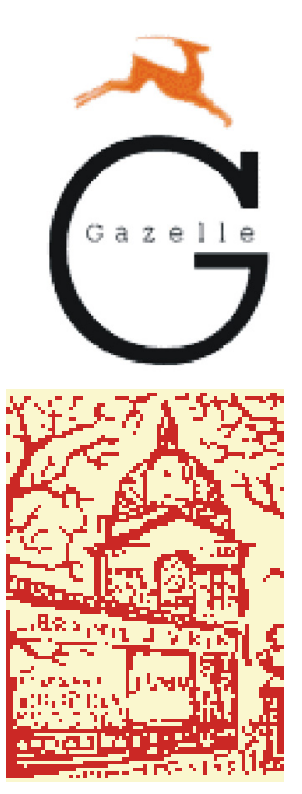
United Kingdom, Ire, Iceland, Turkey, Malta, Portugal by
Gazelle Books Services Limited
White Cross Mills
Hightown
LANCASTER, LA1 4XS
sales@gazellebooks.co.uk

\author{
Livraison pour la France et la Belgique: \\ Librairie Philosophique J.Vrin \\ 6, place de la Sorbonne ; F-75005 PARIS \\ Tel. +33 (0)1 43540347 ; Fax +33(0)1 43544818 \\ www.vrin.fr
(C)2011 ontos verlag
P.O. Box 15 41, D-63133 Heusenstamm nr. Frankfurt
www.ontosverlag.com

ISBN: 978-3-86838-090-3

2011

\begin{abstract}
No part of this book may be reproduced, stored in retrieval systems or transmitted in any form or by any means, electronic, mechanical, photocopying, microfilming, recording or otherwise without written permission from the Publisher, with the exception of any material supplied specifically for the purpose of being entered and executed on a computer system, for exclusive use of the purchaser of the work

Printed on acid-free paper ISO-Norm 970-6

This hardcover binding meets the International Library standard

Printed in Germany

by CPI buch bücher.de
\end{abstract}

